\title{
NEWS LETTER
}

\section{Newfoundland Division}

The 1958-9 programme of the Newfoundland Division is now underway, and as in previous years an attempt is being made to have meetings at least once monthly. Usually the meetings are in two parts. First, there is a clinical session, which is combined with a clinical session of the Department of Anaesthesia of the St. John's General Hospital, and this is followed by a business meeting, where various general and local problems, affecting anaesthetists, are discussed. These have been interesting and successful, and we are hoping to increase the frequency of these meetings.

The General Hospital now has four residents in training in anaesthesia, whereas formerly there were only two. Dr. Pimblett and Dr. Francis, from Britain, have joined the department in the past few weeks, and we are fortunate to have them. Their presence should facilitate our clinical programmes considerably.

$\mathrm{We}$ feel the standards of anaesthesia are gradually improving, and there is great interest generally in the specialty by doctors other than anaesthetists, as well as increasing awareness of its importance by the laity.

The government-sponsored Children's Health Scheme, inaugurated last February, continues, and there has been general satisfaction with it to date.

Anaesthetic equipment in all the hospitals is improving, so that most of them now are adequate in this regard.

Dr. Hazel Peisley, formerly a resident at the St. John's General Hospital, is now practising anaesthesia in St. John's; so the shortage of anaesthetists has been somewhat relieved.

\section{New Brunswick Drvision}

The New Brunswick Division held a business meeting during the meeting of the New Brunswick Medical Association at St. Andrews on August 28, 1958. It was decided that the executive of the division should remain in Mancton for another year.

A Maritime Regional Meeting will be held at the Brunswick Hotel in Moncton on April 17 and 18, 1959. Plans call for two outside speakers and papers from Halifax, St. John, Charlottetown, and Moncton.

The Moncton group are again carrying on their Monday night clinical meetings, and hope to initiate the use of audio-digest tapes.

\section{Quebec Division}

On September the 3, 1958, Dr. Roger Gagnon, Chief Anaesthetist, Sacré-Cour Hospital, Montreal, was elected to the Board of Governors of the College of Physicians and Surgeons of the Province of Quebec. We take this opportunity to offer him our sincere congratulations and to wish him success as our official representative to the provincial governing body. 
On May 19, 1958, the Quebec Division held its first scientific and social meeting of the 1958-59 session. In the morning, a scientific clinical programme was offered by the various Montreal hospitals. In the afternoon, the Hon. Sarto Fournier, Mayor of Montreal, received the members at a cocktail and buffet at the Montreal Botanical Gardens. There were over two hundred guests present at this very successful gathering. Dr. Wilder Penfield was guest-speaker at the evening reception which was held in the main pavillion of the Botanical Gardens.

On October 25, 1958, the Quebec Division held its fall meeting. Over fifty members attended this scientific reunion which was held at the Montreal Children's Hospital. Dr. Harold T. Davenport, Director of Anaesthesia of this hospital was host to the members of the Society. Clinical demonstrations occupied the morning session. In the afternoon interesting presentations on paediatric anaesthesia were delivered by Dr. Jose Rosales and Dr. Paul Quan. Dr. Davenport gave an interesting account of anaesthesia for open-heart surgery as carried out in his Hospital.

On this occasion, an executive meeting presided over by Dr. Jean-Paul Déchène was held to discuss undergraduate and post-graduate teaching of anaesthesia in the Province of Quebec. Doctor Déchène reported on Dr. Fernando Hudon's well-organized undergraduate teaching programme at Laval University. The other university centres are attempting to include anaesthesia on the junior intern rotation programme on a compulsory basis.

A concerted effort is being made to create post-graduate teaching standards in all university centres, particularly in reference to the teaching of basic sciences.

A general meeting was held to discuss local problems and future meetings.

We regret to announce that the following members have passed away and we offer our sincere condolences to their families.

On August 30, 1958, Dr. Rémus Laurendeau, of Montreal, died at the age of 59 .

On April 20, 1958, Dr. A. Legendre, of Shawinigan Falls, died at the age of 34 .

A research fellowship in anaesthesia will commence at the Royal Victoria Hospital, Montreal, on July 1, 1959.

The purpose will be to assist and train young men with special interest and ability in clinical research. The plan will be supported financially by Abott Laboratories Limited and the Department of Anaesthesia of the Royal Victoria Hospital, and will be known as the Abbott Research Fellowship.

The fellowship will carry a stipend of $\$ 7,200.00$ annually and will be open to senior post-graduate students and recent candidates for qualification in anaesthesia. Preference will be given to applicants from Canada and the United Kingdom. 


\section{Ontario Division}

The Ontario Division held a combined meeting with the Section on Anaesthesia of the Ontario Medical Association at London, Ontario, on September 27, 1958. One hundred and fifty physicians and their guests were registered. Dr. Philip Bromage, of the Royal Victoria Hospital, Montreal, was guest speaker. Nineteen exhibitors attended with interesting and pleasing displays.

\section{Manitoba Division}

Dr. Hugh Camrass of St. Boniface Hospital, was married in July.

Dr. Murray Tanasichuk has recently left St. Boniface Hospital to become a resident under Dr. F. H. VanBergen at the University of Minnesota.

Dr. J. McCammon has joined the staff of the Winnipeg General Hospital, having recently completed his training at the Mayo Clinic.

The Winnipeg Anaesthetists' Society held their opening meeting of the 1958-9 season at the Medical Arts Club Rooms on Monday, October 6. This, a dinner meeting, was honoured by the presence of Dr. Philip Bromage of Montreal, who spoke on some aspects of compliance and ventilation and epidural anaesthesia as applied to the relief of intractable pain.

\section{Alberta Division}

Business meetings of the Alberta Division of the Canadian Anaesthetists' Society were held in Calgary, March 13, 1958, and in Lethbridge, September 30, 1958. Both of these meetings were well attended and very informative. Minutes of these meetings were mailed to every Alberta member. It was stressed that every anaesthętist in Alberta should be a member of the Canadian Anaesthetists' Society.

The new fee schedule adopted by Alberta in 1958 appears to be quite satisfactory to most of our anaesthetists.

Regular monthly scientific meetings are held in Edmonton, and regular weekly seminar meetings are held at the University of Alberta in Edmonton.

The Alberta Division is at present negotiating with the University of Alberta as to the possibility of holding a two-day refresher course in anaesthesia in Edmonton.

The Committee on Anaesthetic Deaths in Alberta was active during 1958, and some very instructive information was received. 